\title{
The Influence of Work-life Balance and Achievement Motivation on Athlete Satisfaction
}

\author{
Guntur Pawoko ${ }^{1}$, Wibowo ${ }^{2}$, and Hamidah ${ }^{3}$ \\ \{guntur@hotmail.com ${ }^{1}$ \} \\ Universitas Negeri Jakarta, Rawamangun Muka 13220, Indonesia
}

\begin{abstract}
Athlete satisfaction is a problem that needs to be considered in Indonesia. This research aims to determine the effect of work-life balance and achievement motivation on athlete satisfaction in Indonesia. This research uses a quantitative research approach with t-test and F-test. In this study using a multiple regression analysis method with a total sample of 281 athlete in Indonesia. The analytical tool used in this study is SPSS. The result of this study show that partially (1) work-life balance has a positive effect on athlete satisfaction ,(2) achievement motivation also has a positive effect on athlete satisfaction, (3) work-life balance dan achievement motivation simultaneously have a positive effect on athlete satisfaction in Indonesia. Work-life balance has the greatest effect than achievement motivation to athlete satisfaction in Indonesia.
\end{abstract}

Keywords: Work-Life Balance, Achievement Motivation, Athlete Satisfaction.

\section{Introduction}

Indonesian athletes have been proved successfully competed with foreign athletes as they bring up Indonesia in worldwideIndonesia doesn't only have skilled athletes, but also gifted with many amount of athletes. In 2018, Asian Games was held in Indonesia and became center of attention. Based on the amount of athletes who participated in Asian Games 2018, Indonesia participated by 935 athletes, while China with 859 athletes, Thailand with 812 athletes, South Korea with 775 athletes, and Japan with 761 athletes. In Asian Games 2018, Indonesia was in the fourth rank with 98 medals, meanwhile in Asian Games 2014, Indonesia was ranked 18th with 20 medals in total. With the achievement's improvement, Indonesian athletes have the accomplishment and potential to compete. [1] but those potential and opportunity is not equal with satisfaction improvement of the athletes

Indonesian athletes got problem related by satisfaction matters [2]. (work satis-faction is a positive attitude for labors towards their jobs. Research towards job satis-faction especially for athletes is really rare. Job satisfaction as athletes is really im-portant for Indonesian government. If the company can't reach athlete's satisfac-tion, there will be threat to create athlete's desire to stand up for another country. If this thing happens, it won't just harm Indonesia's government, but also the athletes won't finish the training that has been arranged by the organization. The chance of hijack and transfer athletes has shown business transaction in sport. The athletes already have value which is precious for theirselves, so that the seizing between or-ganizations will happen. This things are the one that makes Indonesian athlete's sat-isfaction very important). 
Athlete's satisfaction is suspected to be caused by achievement motivation [3]. Declared that the significant influence is happening toward work attitudes which consist of work satisfaction. Individuals who have motivation achievement will have good performance because of work satisfaction. Achievement motivation leading to increased job satisfaction [4]. Achievement motivation is part of motivation [5] De-clared that if someone admire something, then he will be motivated to take action to achieve the wish list.If that hope is accomplished, then so does the satisfaction. Work life balance can give equal relation between private life and work and that matters will improve satisfaction in one self. With the accomplishment of satisfaction about their work and family, so that someone will enjoy the benefits of work life balance program that is served)

Work life balance also can give influences toward satisfaction improvement [6]. Work life balance refers to equality of responsibilities in work field, home and anoth-er life aspect. For Indonesian athletes, the schedule or rules that is applied can bear non-equality life work which is not really good for athletes instance rules which are applied for Indonesian athletes is giving boundaries for communication devices utili-zation. The importance of athlete's work life balance is noteworthy, if there is too much time section which is used to practice with job, so that will affect uncomforta-ble feelings.

Research which connected with athlete's satisfaction is still very low [7]. Even though athlete's satisfaction has a very big positive impact toward organizational outcomes like increasing commitment, lower intention to quit, increased job perfor-mance and increase organizational citizenship behavior.

\section{Literature Review}

\subsection{Athlete Satisfaction}

[8] Satisfaction refers to some improvement to complete necessity, will and desires). [9] Work satisfaction is emotional condition that please which created by job mark or someone's job experience. That definition will emphasize the feeling and the employee's mindset about the job, so that the work satisfaction can be very subjective depends on every individual in the organizations [10]. Work satisfaction is defined with positive feeling about job which created from its characteristics. A job isn't just about finishing the given task, but it also need interaction with colleague and superior, follow the rules, and policy of the organisation, accomplish the standard performance, live with different work performance, and stuffs. Work satisfaction refer to general attitude of people toward their job [5]. Someone with high work satisfaction handle positive attitude toward job meanwhile someone who is not satisfied with their job will have negative attitude toward their job. From expert's definition, it can be concluded that work satisfaction is a situation and positive respond of individual which please their job, hopes and achievements in current time as regarding their job with indicator. (1) Pleasant condition for work, (2) Employee's emotional respond towards the achievement, (3) Employee's emotional respond towards their hopes, (4) Employee's pleasant feeling toward their job for certain time.

\subsection{Work-Life Balance}

Work life balance is a relation between job which is paid and citizen's life out of their job, where the balance feeling which is achieved in this relation is really depending on someone's needs, hopes and aspiration. [6] bring up the definition about work life balance is where job means paid work and life is everything beside the formal job, but usually used as directing 
family domain. [12] Work life balance is about individ-ual who have control of when, where and how they work. Balance can be reach when an individual who has right to get a better life can be achieved in inside and outside his job, receive appropriate compensation and honored as norm to give benefit to each of that individual, his organization and his citizens. It can be concluded that work life balance is the situation where someone can effectively arrange profession-alism with life compared achievement in certain times with the indicator: (1) individual capability in keeping relation between works and needs, (2) Relation between professionalism and individualism and, (3) The capability of arranging time effec-tively.

\subsection{Achievement Motivation}

Achievement is something that has been achieved and show the efforts in it [13],[14] achievement motivation is a combination between to personalities, which is tendency of success method and tendency to avoid failure. Beside that, [15] bring up that achievement motivation is a psychology personality concept and continue when someone will enjoy challenging task. Achievement motivation is the idea of intrinsic motivation. Can be concluded that achievement motivation is a motive that makes individual desire to work hard to achieve the goal that is challenging with skills and capability by indicator: (1) Individual desire to win (2) individual desire to be brave to take risk (3) Individual desire to work hard to reach the goal and, (4) Individual desire to have will to avoid failure

\section{Research Methodology}

\subsection{Data}

The data in this research is based on primer data using questionnaire. Question-naire is shared to Indonesian athletes which is registered as athletes in Asian Games 2018.

\subsection{Population And Sampling}

Population in this research is entire Indonesian athletes which is 935 athletes. The amount of sample that is used in this research is 281 athletes with Slovin formula which error amount $5 \%$.

\subsection{Analytical Technique}

This research is a quantitative research which use double regression analytical. Work-life balance dan achievement motivation is an independent variable mean-while profession satisfaction is dependent variable. Data will be proceed with SPSS device by testing hypothesis with t-test and f-test.

\section{Result and Discussion}

\subsection{Hipotesis Testing}

Table 1 Coefficients 
Coefficients $^{\text {a }}$

\begin{tabular}{|c|c|c|c|c|c|c|}
\hline \multirow{2}{*}{\multicolumn{2}{|c|}{ Model }} & \multicolumn{2}{|c|}{ Unstandardized Coefficients } & \multirow{2}{*}{$\begin{array}{c}\text { Standardized } \\
\text { Coefficients }\end{array}$} & \multirow[b]{2}{*}{$t$} & \multirow[b]{2}{*}{ Sig. } \\
\hline & & $\mathrm{B}$ & Std. Error & & & \\
\hline \multirow[t]{3}{*}{1} & (Constant) & -.708 & .230 & & -3.081 & .002 \\
\hline & Work-Life Balance & .988 & .055 & .744 & 18.072 & .000 \\
\hline & Achievement Motivation & .251 & .069 & .149 & 3.613 & .000 \\
\hline
\end{tabular}

a. Dependent Variable: Athlete Satisfaction

Based on table 1, we can see partially (t-test), work-life balance affect significantly towards Athelete Satisfaction with p-value 0,000 which means $<0,05$. Achievement Motivation also affect significantly towards p-value, 000 which means $<0,05$. Work-Life Balance has a bigger positive impact towards athlete's satisfaction in the amount of 0,744 whereas achievement motivation has positive impact in the amount of 0,149 )

Table 2. Anova

ANOVA $^{\text {a }}$

\begin{tabular}{|ll|r|r|r|r|l|}
\hline \multicolumn{1}{|c|}{} & \multicolumn{1}{c|}{$\begin{array}{c}\text { Sum of } \\
\text { Sodel }\end{array}$} & \multicolumn{1}{c|}{ df } & Mean Square & \multicolumn{1}{c|}{ F } & Sig. \\
\hline 1 & Regression & 127.799 & 2 & 63.899 & 347.557 & $.000^{\mathrm{b}}$ \\
& Residual & 51.111 & 278 & .184 & & \\
& Total & 178.910 & 280 & & & \\
\hline
\end{tabular}

a. Dependent Variable: Athlete Satisfaction

b. Predictors: (Constant), Achievement Motivation, Work-Life Balance

Table 2. Model Sumary

Model Summary

\begin{tabular}{|l|l|r|r|r|}
\hline Model & R & R Square & $\begin{array}{c}\text { Adjusted R } \\
\text { Square }\end{array}$ & $\begin{array}{c}\text { Std. Error of } \\
\text { the Estimate }\end{array}$ \\
\hline 1 & $.845^{\mathrm{a}}$ & .714 & .712 & .42878 \\
\hline
\end{tabular}

a. Predictors: (Constant), Achievement Motivation, Work-Life Balance

b. Dependent Variable: Athlete Satisfaction

Based on table 2 and table 3, can be seen that simultaneously (F test), work life balance and achievement motivation significantly affect athlete's satisfaction with p-value 0,000 which means $<0,05)$. The affect of work life balance and achievement motivation simultaneously in the amount of 0,714$)$.

\subsection{Discussion}

This research has shown that work life balance affect positively and significantly towards athlete satisfaction. Work life balance also has big impact compared to achievement motivation toward athlete satisfaction. As an athlete, this research is also parallel to the research which is done by [16]. Indonesian athletes have had mature training schedule, so that the athletes will be harder to have a good relation with family and friends. Sport organization especially the ministry of 
the youngster and sport needs to consider the provision of time for the athletes in order that the athletes can spend more time with family and friends. With that concern, as expected the athletes will have positive attitude and performance or glorious achievement)

Achievement motivation is also affect positively and significantly towards athlete satisfaction. This result is also parallel to the research of [17]. Achievement motivation is needed for the athlete. The athlete must feel happy, boast and comfortable so that they can have satisfaction towards his profession. With achievement motivation, the athletes is expected not only to have good attitude, but also have the positive mind and willing to achieve)

\section{Conclusion}

Work-life balance have affected positively and significantly toward athlete satisfaction. Achievement motivation has affected positively and significantly toward athlete satisfaction. Work life balance and achievement motivation have affected simultaneously toward athlete satisfaction.

\section{REFERENCES}

[1] Tempo.co, https://asiangames.tempo.co/read/1118347/asian-games-2018-dibuka-ini-kontinganterbanyak-dan-tersedikit/, last accessed 2018/08/18

[2] Fattah, H. Kepuasan Kerja \& Kinerja Pegawai : Budaya Organisasi, Perilaku Pemimpin dan Efikasi Diri. Elmatera, Yogyakarta (2017).

[3] Lee, H.W., Liu C.H. The Relationship Among Achievement Motivation, Psychological Contract and Work Attitudes. Social Behavior and Personality 37 (3), 321-328 (2009).

[4] Lambrou, P., Kontodimopoulos, N., Niakas, D. Motivation and job satisfaction among medical and nursing staff in a Cyprus public general hospital. Human Resources For Health 8(26), 1-9 (2010).

[5] Kreitner, R., \& Kinicki, A. Perilaku Organisasi. Salemba Empat, Jakarta (2014).

[6] Adikaram, \& Jayatilake, L. V. Impact Of Work Life Balance On Employee Job Satisfaction In Private Sector Commercial Banks Of Sri Lanka. International Journal Of Scientific Research And Innovative Technology 3(11), 17-31 (2016).

[7] Burns, G.N., Jasinski, D., Dunn, S.C., Fletcher, D. Athlete identity and athlete satisfaction : The noncoformity of exclusivity. Personality and Individual Differences 52, 280-284 (2012).

[8] Sageer, A., Rafat, S., \& Argawal, P. Identification of Variables Affecting Employee Satisfaction and Their Impact on The Organization. Journal of Business and Management 5(1), 32-39 (2012).

[9] Colquitt, J. A., Lepine, J. A., \& Wesson, M. J. Organizational Behavior: Improving Performance And Commitment In The Workplace, Fourth Edition. Mcgraw Hill Education, United States (2015).

[10] Robbins, S. P., \& Judge, T. Organizational Behaviour : Global Edition 16/E. Pearson Higher Education, San Diego (2015).

[11] Lee-Ross, D., Pryce, J. Human Resources and Tourism : Skills, Culture and Industry. Channel View Publications, UK (2010).

[12] Schadel, C. Work-Life Balance Among Cruise Ship Crews. Diplomica Verlag, Hamburg (2011).

[13] Lo, H.H.M., Li, N.H.C. Exploring the effect of Staff Achievement on Job Satisfaction in Hong Kong Residential Clubhouse. Journal of Tourism \& Hospitality 5(6), 1-8 (2016).

[14] Singh, K. Study of Achievement Motivation in Relation to Academic Achievement of Students. International Journal of Educational Planning \& Administration 1(2), 161-171 (2011). 
[15] Zhao, X., Jia, L \& Maes, J.H.R. Effect of achievement motivation on cognitive control adaptations. Journal of Cognitive Psychology, 30(4), 453-465 (2018).

[16] Haar, H.M., Russo, M., Sune, A., Ollier-Malaterre, A. Outcomes of work-life balance on job satisfaction, life satisfaction and mental health: A study across seven cultures. Journal of Vocational Behavior 85, 361-373 (2014).

[17] Hayati, K., Caniago, I.: Islamic Work Ethic : The Role of Intrinsic Motivation, Job Satisfaction, Organizational Commitment and Job Performance. In : International Congress on Interdisciplinary Business and Social Science, pp. 1102-1106. Elsevier Ltd, Jakarta (2012). 